\title{
Earthworm services for cropping systems. A review
}

\author{
Michel Bertrand • Sébastien Barot • Manuel Blouin • \\ Joann Whalen • Tatiana de Oliveira • \\ Jean Roger-Estrade
}

Accepted: 13 November 2014 / Published online: 22 January 2015

(C) INRA and Springer-Verlag France 2015

\begin{abstract}
Intensive agriculture is often criticized for negative impacts on environment and human health. This issue may be solved by a better management of organisms living in crop fields. Here, we review the benefits of earthworms for crops, and we present techniques to increase earthworm abundance. The major points are the following: (1) Earthworms usually improve soil structural stability and soil porosity and reduce runoff. (2) Earthworms modify soil organic matter (SOM) and nutrient cycling. Specifically, earthworms stabilize SOM fractions within their casts, and they also increase the mineralization of organic matter in the short term by altering physical protection within aggregates and enhancing microbial activity. (3) The positive correlation between earthworm abundance and crop production is not systematic, and contrasting effects on yields have been observed. Earthworms induce the production of hormone-like substances that improve plant growth and health. (4) Direct drilling increases earthworm abundance and species diversity, but the beneficial effect of reduced tillage depends upon the species present and tillage intensity. (5) Organic amendments enhance earthworm abundance. (6) Earthworms feeding
\end{abstract}

M. Bertrand · T. de Oliveira $\cdot$ J. Roger-Estrade

INRA, UMR, 211 Agronomie, 78850 Thiverval-Grignon, France

M. Bertrand $(\bowtie) \cdot$ T. de Oliveira $\cdot$ J. Roger-Estrade

AgroParisTech, UMR 211 Agronomie, 78850 Thiverval-Grignon,

France

e-mail: michel.bertrand@grignon.inra.fr

S. Barot

IRD, IEES-P (IRD, CNRS, UPMC, UPEC), ENS, 46 rue d'Ulm, 75230 Paris Cedex 05, France

\section{Blouin}

Université Paris-Est, IEES-P (IRD, CNRS, UPMC, UPEC),

61 Avenue du Général De Gaulle, 94010 Créteil, France

J. Whalen

Department of Natural Resource Sciences, Macdonald Campus, McGill University, Ste Anne de Bellevue, QC H9X 3V9, Canada at soil surface are the most exposed to pesticides and other agrochemicals. Finally, we discuss how to combine management practices, including inoculation, to increase the earthworm services. We conclude that using earthworm services in cropping systems has potential to boost agricultural sustainability.

Keywords Earthworms · Tillage · Pesticides ·

Mineralization · Belowground-aboveground interactions .

Soil structure $\cdot$ Crop pathogens and parasites $\cdot$ Ecosystem services

Contents

1. Introduction $\ldots \ldots \ldots \ldots \ldots \ldots \ldots \ldots \ldots$

2. Effects of earthworms on soil fertility, crop growth and health............................

2.1. Earthworm activity and soil structure: consequences for erosion and soil water regime ............

2.2. Effect of earthworms on soil organic matter decomposition and nutrients cycling $\ldots \ldots \ldots \ldots \ldots \ldots$

2.3. Effects of earthworms on crop growth and health ...

3. Effects of cultural practices on earthworm communities in cultivated fields .......................

3.1. Tillage. . . . . . . . . . . . . . . . . . .

3.2. Organic amendments. . . . . . . . . . . . . . .

3.3. Pesticides application ................

4. Managing earthworm beneficial effects in cropping systems 5. Conclusion . . . . . . . . . . . . . . . . . . . . .

\section{Introduction}

Earthworms generally have positive effect on many ecosystem services such as pedogenesis, development of soil structure, 
water regulation, nutrient cycling, primary production, climate regulation, pollution remediation, and cultural services (Blouin et al. 2013). They have long been used in traditional medicine (Shen 2010), due to the various chemical compounds they contain (Grdiša et al. 2013). With a high content of proteins, about $60-70 \%$, they represent a valuable feed for fish (Olele and Okonkwo 2012) or poultry (Tiroesele and Moreki 2012). They can also be a delicacy for some people, like for Ye'Kuana Amerindians in Venezuela, who eat them both raw and smoked (Paoletti et al. 2003). They attract more and more attention for their ability to reduce organic waste into valuable compost called "vermicompost" (Fig. 1). Indeed, the burial of organic wastes or their incineration is an inappropriate use of the energy and organic carbon contained within the material at a time when fossil energy is becoming increasingly expensive and $\mathrm{CO}_{2}$ release a major global problem. Vermicomposting of locally produced organic wastes decreases the cost of transport to water treatment plants, incinerators, or landfills (Edwards et al. 2011). Vermicomposting represents an opportunity to turn organic waste into a fertilizer and soil conditioner that is beneficial for plant growth either at home, in greenhouse, or even in the field (Arancon and Edwards 2011). These advantages make vermicomposting a powerful tool for environmental education (Appelhof et al. 1993).

In agriculture, the beneficial effects of earthworms could help to overcome some of the major issues of conventional intensive farming (Table 1). Compaction is a major problem in humid areas. In these cases, earthworms could help to alleviate structure degradation, especially if simplified tillage systems are to be adopted. In conventional agriculture, with highyield objectives, the amount of nutrients required and nitrateleaching risk is often high. When organic amendments are applied, earthworms could boost organic matter mineralization and improve nutrient bioavailability. Moreover, nutrient release due to earthworm activity is temporally and spatially synchronized with plant activity. Indeed, through the creation of small patches (the casts) enriched in mineral nutrients, they could contribute to enhance nutrient use efficiency and to decrease the risks of nitrate leaching. Furthermore, reaching high yield levels implies a high protection level against pests and diseases. Here again, earthworms could help: There is evidence that earthworms help crops to be more resistant or tolerant to diseases and pests and/or could be an effective agent for biological control of soil pathogens. The interactions between earthworms, soil functions, and plant growth and the beneficial effects emerging from these interactions are summarized on Fig. 2.

However, these earthworm-mediated ecological services are both site- and species-dependent and may not always improve the performance of cropping systems. For instance, turnover of soil organic matter (SOM) and nutrients, accelerated by earthworms, could stimulate the production of greenhouse gases like carbon dioxide $\left(\mathrm{CO}_{2}\right)$ and nitrous oxide $\left(\mathrm{N}_{2} \mathrm{O}\right)$, as shown by the meta-analysis of Lubbers et al. (2013). Nevertheless, it is generally assumed that abundant earthworm populations are beneficial to agriculture.

Since earthworms live within agroecosystems, cultural practices exert a top-down effect on earthworm populations. Earthworm species richness, the size and structure of earthworm populations (number of individuals, ratio of juveniles/ adults), and their biomass are dependent on crop management (Riley et al. 2008; Pelosi et al. 2009). The main cultivation practices whose influence on earthworm populations is recognized are summarized on Table 2. The effect of tillage on earthworm community composition and abundance is highly dependent on the intensity and scheduling of tillage operations. The organic matter supplied to the soil is also a key driver of earthworm abundance. Earthworm effects on plant growth or soil pathogens are expected to be highly dependent on soil properties such as SOM or water content, which are also affected by cultural practices. Pesticides are not always without influence on earthworms. Last, the influence of cropping systems has also to be evaluated at the territory level: Crop diversity, hedges, and land use have an influence on the spatial distribution of earthworm species. However, this aspect will not be taken into account in this paper, due to the scarcity of studies reported in the literature.

To design crop management systems that consider the value of earthworms explicitly, it is necessary to assess the earthworm-mediated ecological services that occur in cropped fields and to review the effects of cultivation practices on earthworm diversity, abundance, and activity. In this paper,
Fig. 1 Vermicompost can be obtained in about 100 days from domestic organic wastes when processed by the earthworms Eisenia fetida or Eisenia andrei. Photographs by M. Blouin
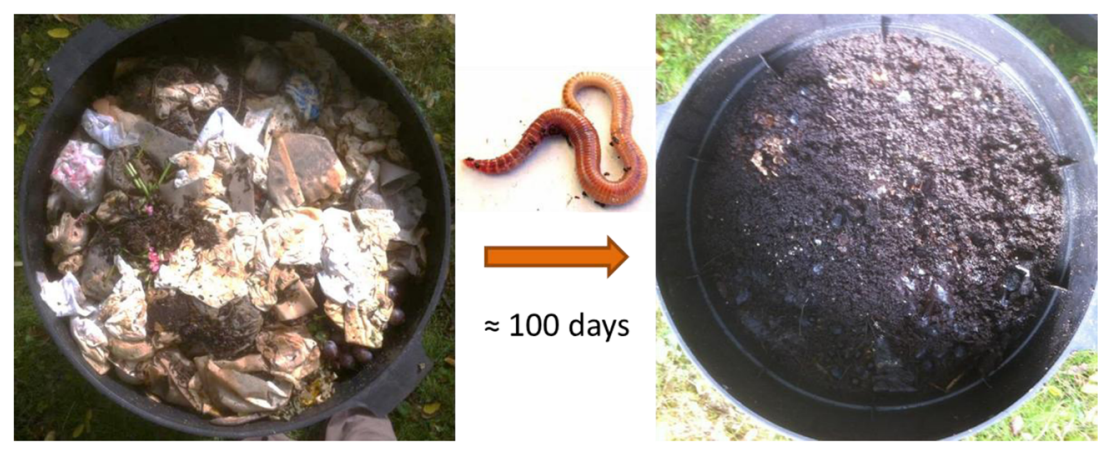
Table 1 Lists of agricultural issues that constrain profitable crop production, together with the ways that earthworms could help to solve these problems

\begin{tabular}{lc}
\hline Agricultural issues & Mechanisms through which earthworms can help \\
\hline Deterioration of the structure of cultivated soils & $\begin{array}{c}\text { Earthworms improve soil aggregation and macro- } \\
\text { porosity through their casts and galleries } \\
\text { Eow organic matter content in cultivated soils } \\
\text { within their casts } \\
\text { Cultivated plants require large inputs of mineral } \\
\text { nutrients and nutrient losses must be reduced }\end{array}$ \\
$\begin{array}{c}\text { Earthworms accelerate nutrient mineralization on the } \\
\text { short term. Plant growth could be temporally and }\end{array}$ \\
spatially synchronized with earthworm casting \\
activities, creating of small patches enriched in \\
Pesticides use should be reduced, seek more & mineral nutrients and hormone-like effects \\
sustainable ways to control pests and pathogens & Earthworms may decrease the negative impacts of \\
& some pests and pathogens (nematodes, fungi) \\
\hline
\end{tabular}

we first review the effect of earthworms on soil fertility (including soil structure, SOM and nutrient dynamics, and microbial activities), plant growth, and plant health. We then discuss the effect of cultivation practices on earthworm communities: tillage, organic amendments, and pesticide application. Finally, we discuss how earthworms could be integrated in cropping systems to enhance agricultural productivity and sustainability.

\section{Effects of earthworms on soil fertility, plant growth, and health}

\subsection{Earthworm activity and soil structure: consequences for erosion and soil water regimes}

Soil structure is a critical factor for most soil functions, including soil fertility. Earthworms contribute to soil structure

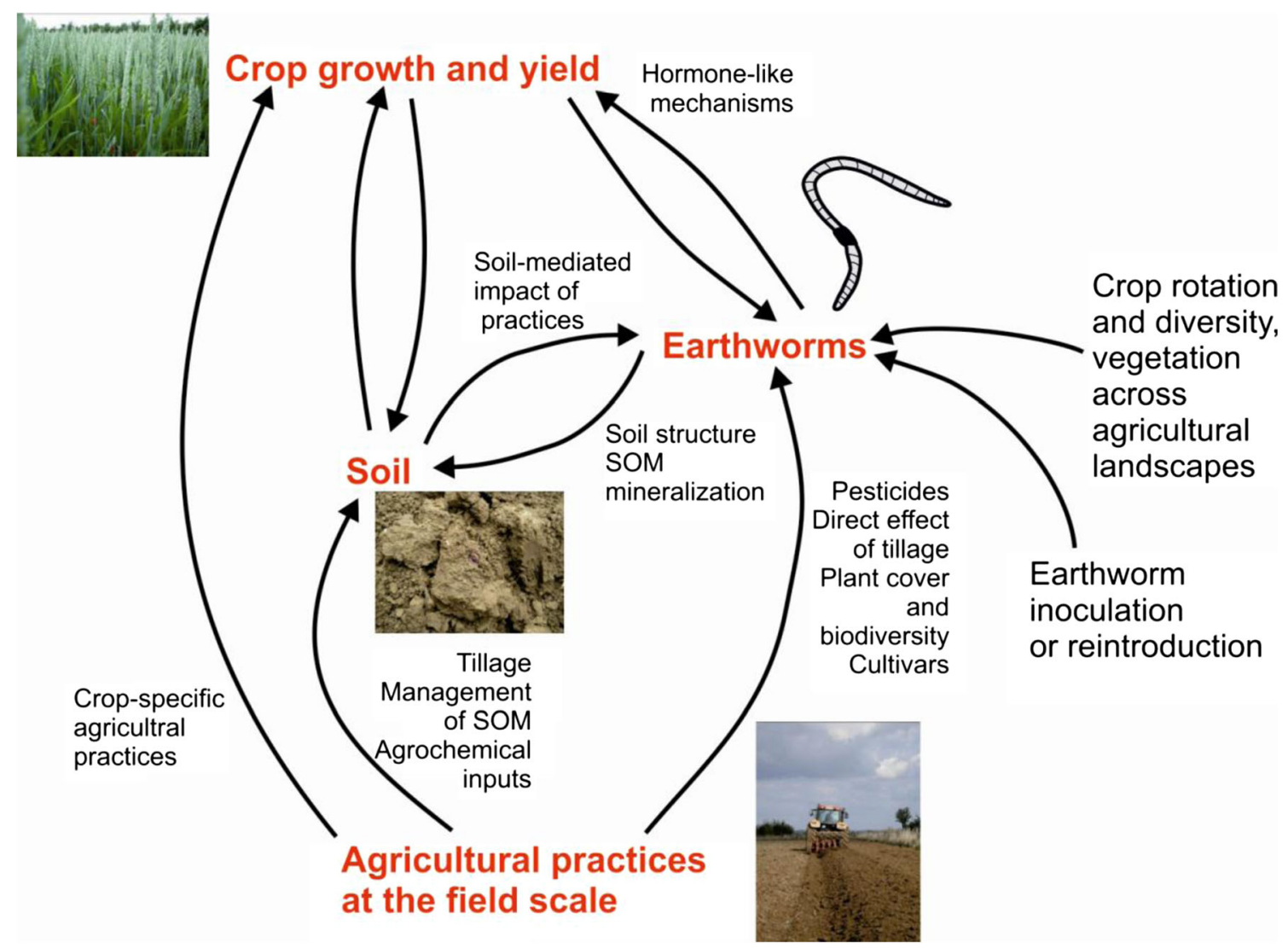

Fig. 2 Earthworms provide similar outcomes as cultural practices, on crop nutrition, health and yield. The magnitude of the earthworm-induced changes in soil structure, water and nutrient availability, and hormonelike effects on crop health is affected by the size and activity of earthworm populations and other site-specific factors affecting the ability of earthworms to modify the soil fertility and crop growth. Cultural practices such as tillage and organic matter inputs are expected to regulate the size and activity of the earthworm community. Photographs by M. Bertrand 
Table 2 Challenges to maintain large, active populations of earthworms in agroecosystems and possible solutions

\begin{tabular}{ll}
\hline $\begin{array}{l}\text { Effects of cultivation operations in conventional } \\
\text { agriculture }\end{array}$ & $\begin{array}{l}\text { Changes in cultivation practices beneficial to } \\
\text { earthworms }\end{array}$ \\
\hline $\begin{array}{l}\text { Tillage tends to reduce earthworm populations, } \\
\text { especially anecics. }\end{array}$ & No-tillage or reduced tillage \\
$\begin{array}{c}\text { Some pesticides impact earthworm populations } \\
\text { negatively }\end{array}$ & $\begin{array}{c}\text { Reduced use of pesticides; alternative ways to } \\
\text { control pests and pathogens }\end{array}$ \\
$\begin{array}{l}\text { In conventional agriculture, organic amendments are } \\
\text { scarce and litter availability is reduced. }\end{array}$ & $\begin{array}{c}\text { Increase soil organic matter supply; reduce } \\
\text { tillage;introduce cover crops; agro-forestry. }\end{array}$ \\
$\begin{array}{l}\text { Simplification of crop sequence, elimination of } \\
\text { ecological infrastructures (hedges, woods,...). }\end{array}$ & $\begin{array}{c}\text { Diversification of the crop sequence, introduction of } \\
\text { permanent pastures, (re)conception of ecological } \\
\text { infrastructure. }\end{array}$ \\
\hline
\end{tabular}

and formation through humus formation, mineral weathering, and mixing of these components to create stable aggregates, i.e., organo-mineral complexes, which are deposited either on the soil surface or within the soil profile (Le Bayon et al. 2002). They also affect soil mechanical and hydraulic properties through their burrowing activities (Fig. 3a), which generate macropores that significantly impact water infiltration and thus are important for supplying crops with water, as well as controlling surface runoff and erosion.

Burrowing is driven by earthworm activities such as feeding, reaction to drought or cold temperatures, avoidance of predators, and soil oxygenation (Jegou et al. 2002). Pore morphology varies depending on the earthworm ecological group. Anecic earthworms (Fig. 3b) dig large (higher than 1$\mathrm{mm}$ diameter) vertically oriented galleries that extend to depths greater than $1 \mathrm{~m}$ in the soil profile. Endogeic earthworm (Fig. 3c) galleries are not preferentially oriented in the vertical direction. The burrow diameter is smaller than anecic burrows, and they are not so deep (Bouché 1972). Epigeic earthworms remain in the litter layer and in the first few centimeters of the soil and thus have little effect on soil macroporosity. In a mesocosm experiment, Ernst et al. (2008) showed that earthworm ecological groups affect soil water characteristics. The anecic Lumbricus terrestris and the endogeic Aporrectodea caliginosa enhanced drying in the 0 $15-\mathrm{cm}$ soil layer by increasing soil aeration and subsequently evaporation through their burrows. In contrast, the epigeic Lumbricus rubellus tended to favor water storage in the topsoil. This is probably due to the fact that L. rubellus leaves litter at the soil surface rather than burying it, which prevents evaporation. A. caliginosa induced higher water infiltration rates and faster water discharges to the subsoil than other species, probably because its burrows are temporary and continually being rebuilt.

Earthworm burrows affect water availability to crops. Blouin et al. (2007) showed, studying rice growing in a greenhouse, that the presence of the endogeic worm Reginaldia omodeoi, formerly known as Millsonia anomala, had a positive effect on plant growth in a well-watered treatment, but a negative effect in a water-deficient treatment. This was attributed to lower water availability to rice caused by lower soil water retention capacity in the presence of this compacting earthworm. However, preferential water flow occurred in macropores created by earthworms. This has been documented for different soil types: rice paddy soils (Sander et al. 2008), temperate loamy soils (Capowiez et al. 2009), and temperate clay soils (Jarvis et al. 2007). Preferential flow increases the risk of leaching and subsequent contamination of subsurface and groundwater by nitrogen and pesticides (Ritsema and Dekker 2000; Blackwell 2000). However, the action of earthworms on soil porosity generally has a positive effect on the soil water regime (Ehlers 1975; Clements et al. 1991; Pitkänen and Nuutinen 1998). Clements et al. (1991) showed that, after 10 years of earthworm inoculation, the water infiltration rate increased from 15 to $27 \mathrm{~mm} \mathrm{~h}^{-1}$. In Mediterranean soils, water percolation was found to be positively correlated with earthworm biomass, burrow length, and burrow surface with $r$ value of $0.66,0.65$, and 0.77 ,
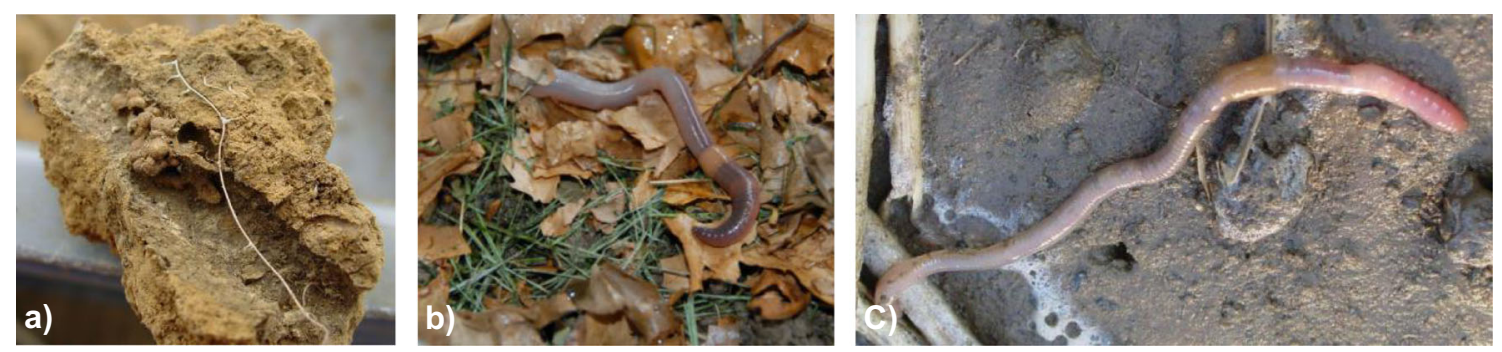

Fig. 3 a Earthworm gallery in a compacted clod of loamy soil in Northern France (credit C. Pelosi). b Anecic earthworm Lumbricus terrestris (credit S. Barot). c Endogeic earthworm Apporectodea rosea (credit C. Pelosi) 
respectively (Bouché and Al-Addan 1997). In this study, a significant correlation between infiltration and earthworm biomass was observed: The infiltration rate increased by $150 \mathrm{~mm} \mathrm{~h}^{-1}$ per $100 \mathrm{~g} \mathrm{~m}^{-2}$ of earthworms. This correlation was even stronger when only anecic species were considered in the analysis: $282 \mathrm{~mm} \mathrm{~h}^{-1}$ per $100 \mathrm{~g}$ of anecic $\mathrm{m}^{-2}$ (Bouché and Al-Addan 1997). In contrast, in a corn agroecosystem where earthworm populations were deliberately elevated, the infiltration rate did not vary (Lachnicht et al. 1997).

Water infiltrating through earthworm burrows can be a source of crop water or percolate through the soil profile, but changes in water infiltration also affect surface hydrological processes. In Ohio, the increase in infiltration rate due to anecic earthworm burrows reduced soil erosion by $50 \%$ (Shuster et al. 2002). In Vietnam on an experimental field with $40 \%$ slope, biogenic aggregates of Amynthas khami were responsible for a $75 \%$ decrease in runoff (Jouquet et al. 2007). Endogeic species also increase soil macroporosity and water infiltration, which tends to reduce runoff. However, it has been shown that some endogeic species also produce small-sized casts, which favor surface sealing and contribute to soil erosion (Blanchart et al. 1999). This effect was shown in tropical conditions with Pontoscolex corethrurus, a tropical earthworm. However, this negative effect resulted from a dramatic population increase of one particular species after the land use was changed from forest to pasture in Brazil (Chauvel et al. 1999). Earthworm species that create water stable casts reduce soil sensitivity to splash effects and runoff, but this may reduce water infiltration by increasing surface bulk density (Reddell and Spain 1991b; Blanchart et al. 1999; Chauvel et al. 1999; Shuster et al. 2002). These contradictions between the results about the impact of earthworms on soil structure, water infiltration, and soil erosion are probably due to the fact that this impact depends on the following: (1) the rainfall regime, (2) earthworm abundance, (3) earthworm species, and (4) the amount of organic matter available at soil surface (Blanchart et al. 1997; Hallaire et al. 2000).

Generally, earthworm burrowing and casting activities contribute efficiently to soil erosion control in temperate and tropical soils. In temperate climates, anecic earthworm casts increased soil roughness, reinforced by the presence of organic residues, forming "middens" that reduced surface runoff (Le Bayon et al. 2002). In Finland, surface runoff during rainfall events was negatively correlated with the dry biomass of L. terrestris (Pitkänen and Nuutinen 1998). In three soil tillage treatments where earthworm populations were reduced, increased, or remained unmanipulated, anecic earthworm biomass was identified as an important independent variable contributing to runoff and erosion diminution, and erosion rates decreased exponentially as a function of anecic earthworm biomass (Valckx et al. 2010). Endogeic and anecic casts on the soil surface improve soil structural stability and give a better resistance to erosion (Le Bayon et al. 2002). They may represent considerable amounts of soil, i.e., 2 to $10 \mathrm{~kg} \mathrm{~m}^{-2}$ in temperate climate, which corresponds to a 5- to $25-\mathrm{mm}$-thick layer created by earthworms.

Although some cases of soil degradation due to earthworm compacting species are reported in the literature, earthworms generally improve soil structural stability and soil porosity and reduce runoff.

2.2 Effect of earthworms on soil organic matter and nutrient cycling

Earthworms contribute to carbon cycling through several complementary mechanisms (Lavelle and Martin 1992; Marinissen and de Ruiter 1993). Anecic and epigeic earthworms directly ingest poorly decomposed litter at the soil surface, while endogeics ingest soil and assimilate a small fraction of the organic matter it contains. Once ingested, the fraction of litter that is not assimilated is fragmented during the digestion process and mixed with soil. Last, the undigested litter and SOM are returned to the soil in the form of earthworm casts. Fresh casts possess active bacteria and high mineralization rates, at least transiently, and these nutrient cycling processes decline with the age of casts.

SOM decomposition and mineralization depend on processes mediated by soil microorganisms. Earthworms change the structure of soil microbial communities in a way that accelerates SOM decomposition and mineralization (see for example Scheu et al. 2002; McLean and Parkinson 2000). Bacteria are strongly implicated in soil organic carbon (SOC) stabilization and nitrogen cycling due to their population size, turnover rates, and ability to produce enzymes required for decomposition/mineralization. While bacteria directly contribute to SOM mineralization, Winding et al. (1997) observed greater protozoa activity in mesocosms with earthworms, which increased mineralization, presumably due to predation of bacteria in the detrivorous food web. Four mechanisms are generally assumed to be responsible for earthworm-microbial interactions (Brown 1995): (i) Soil ingestion stimulates the growth of some microorganisms through the addition of mucus and brings microorganisms in contact with organic residues. (ii) The incorporation of organic matter into the soil creates hot spots of microbial activity. (iii) Earthworms modify soil structure, creating habitats favorable to microbial activity. (iv) Earthworms are responsible for horizontal and vertical transport of microorganisms, which are either transported on earthworm body or in their gut, ingested with soil or litter. While the stimulation of some bacteria within the earthworm digestive tract and in fresh casts is often reported, the long-term effect of earthworms on bacteria biomass in the bulk soil is still under debate. In some studies, bacterial biomass increased in response to earthworm stimulation (Burtelow et al. 1998; Li et al. 2002; Groffman et al. 
2004) and decreased following earthworm consumption in other studies (Hendrix et al. 1998; Groffman et al. 2004).

The short-term increase in mineral nutrient availability in the presence of earthworms is well documented, but the longterm effect of earthworms on SOM content is less clear (Lavelle et al. 1992; Don et al. 2008). Incorporation of organic matter into the soil profile by earthworms might lead to a partial protection of surface litter within the SOM. The evidence for this phenomenon comes first from the lower mineralization observed in old and stable earthworm casts (Pulleman et al. 2005; Bossuyt et al. 2005). Second, the organic matter that reaches a deeper soil layer is less prone to decomposition, which might be due to the lower provision of fresh organic matter to these soil layers that suppresses positive priming effects (Fontaine et al. 2007), i.e., the enhancement of SOM decomposition through inputs of labile organic matter that stimulates microbial activities.

Bohlen et al. (1997) calculated that a population of about 100 individuals per $\mathrm{m}^{2}$ of $L$. terrestris could ingest $840 \mathrm{~kg} \mathrm{ha}^{-1}$ year $^{-1}$ of surface litter in a temperate cornfield. Eriksen-Hamel and Whalen (2007) reported that the availability of soil mineral $\mathrm{N}$, and subsequently the $\mathrm{N}$ concentration in soybean grain, is increased with the abundance of earthworms, mostly A. caliginosa. The increase in $\mathrm{N}$ availability with increasing earthworm abundances can be significant: A field with high earthworm abundance, 300 individuals $\mathrm{m}^{-2}$, could have $14 \mathrm{~kg} \mathrm{~N} h a^{-1}$ more in the $0-15-\mathrm{cm}$ soil layer than a field with low earthworm abundance, 30 individuals $\mathrm{m}^{-2}$. The availability of some of the watersoluble nutrients $(\mathrm{K}, \mathrm{Ca}, \mathrm{Mg}, \ldots)$ is also enhanced as SOM and litter pass through earthworm gut, because these nutrients are solubilized and dissolved from soil minerals during the grinding/rearrangement of organo-minerals during gut transit (Carpenter et al. 2007).

Earthworms may also cause $\mathrm{N}$ losses from ecosystems. For example, earthworms have been shown, in some cases, to increase denitrification (Horn et al. 2006; Costello and Lamberti 2009; Lubbers et al. 2013) and the leaching of mineral N (Domínguez et al. 2004). However, the stabilization of organic $\mathrm{N}$ in earthworm casts could offset these $\mathrm{N}$ losses. Such effects of earthworms on the nitrogen balance have not been assessed thoroughly in agroecosystems, and this knowledge gap needs to be addressed.

In summary, processes underlying earthworm's effects on SOM cycling and nutrient availability are complex, and the balance between positive and negative effects is not clearly established and probably depends on the time of sampling at a specific site.

\subsection{Effects of earthworms on crop growth and health}

Earthworms have inhabited soils for several hundred million years and represent the most abundant belowground biomass in most terrestrial ecosystems (Lavelle and Spain 2001); so, it is likely that coevolution between earthworms and plants could have occurred. The beneficial effect of earthworms on plant growth was recognized more than a century ago (Darwin 1881). Consequently, the effect of earthworms on primary production has been extensively investigated in the laboratory or in the field, respectively, 46 and $54 \%$ of the studies reviewed by Brown et al. (1999), with some experiments monitored for several years (Giri 1995; Blanchart et al. 1997). Here, we give a brief overview of some of the vast literature available on this topic (Lee 1985; Edwards and Bohlen 1996; Lavelle et al. 2001; Edwards 2004).

Brown et al. $(1999 ; 2004)$ reviewed 246 experiments in tropical countries and concluded that in $53 \%$ of the studies, there was less than $20 \%$ difference in biomass production with and without earthworms. In $4 \%$ of studies, there was more than $20 \%$ reduction in biomass production in the presence of earthworms, such that earthworms were detrimental to plant growth. In the remaining $43 \%$ of studies, there was more than $20 \%$ improvement in biomass production where earthworms enhanced plant growth. Several environmental factors were identified as responsible for variation in biomass production in the presence of earthworms (Brown et al. 1999, 2004). A major determinant is soil type, especially soil texture and carbon content, which account for $43 \%$ of the variation in plant yield response. Sandy soils with a slightly acidic $\mathrm{pH}$ show the greatest increase in biomass production in the presence of earthworms (Brown et al. 2004), which was confirmed by Laossi et al. (2010a). Plant functional group is also an important driver: Earthworms induce higher biomass production in perennial species, especially trees, than that in annual species, whereas biomass of legumes is sometimes negatively affected by the presence of earthworms (Brown et al. 2004).

In a review of 67 studies reporting 83 cases located in temperate countries, Scheu (2003) showed that aboveground production increased significantly with earthworms in $79 \%$ of cases, while it decreased significantly in $9 \%$ of cases. Belowground production increased significantly in $50 \%$ of cases and decreased in $38 \%$ of cases. The shoot-root ratio was assessed in $24 \%$ of cases and increased with earthworm abundance in all cases but one study reported by Atiyeh et al. (2000). To summarize, aboveground biomass generally increases in the presence of earthworms, but belowground biomass exhibits a variable response to the presence of earthworms.

The positive correlation between earthworm abundance and crop production is not systematic, and contrasting effects on yields have been observed. For example, a study by Baker et al. (1999) showed that pasture production increased linearly with increasing earthworm abundance, A. caliginosa, Aporrectodea longa, and Aporrectodea trapezoides, being each introduced at 114, 214, 429, and 643 earthworms per $\mathrm{m}^{-2}$. Conversely, Chan et al. (2004) 
reported that the highest grass production, $+49 \%$ higher than that in control without earthworms, was measured in the low abundance treatment, $212 \mathrm{~A}$. longa per $\mathrm{m}^{2}$, not in the high abundance treatment, 424 worms per $\mathrm{m}^{-2}$. This negative effect of high earthworm abundance on crop production is not fully understood, but it could be that adding earthworms above the soil carrying capacity will lead to soil compaction, as observed in Amazonia (Chauvel et al. 1999).

Five mechanisms, reviewed in Brown et al. (2004), are likely responsible for the positive effect of earthworms on plant production. Earthworm-induced changes in soil physicochemical properties, reviewed in Sect. 1, include the following: (i) modification of soil porosity and aggregation, which changes water and oxygen availability to plants, and (ii) greater mineralization of SOM, which increases nutrient availability to the plants. The other three mechanisms involve interactions with other organisms: (iii) biocontrol of pests and parasites, (iv) stimulation of symbionts, and (v) production of plant growth regulators via the stimulation of microbial activity.

Earthworms could be effective for pest biocontrol. For example, earthworms Aporrectodea rosea and A. trapezoides reduced the severity of take all, due to a soil-borne fungal pathogen (Stephens et al. 1994; Stephens and Davoren 1997), and the earthworm $R$. omodeoi reduced the damage caused by plant parasitic nematodes Heterodera sacchari on rain-fed rice plants (Blouin et al. 2005). Earthworms influenced the development of aphids through their effects on plant growth and nutrient content (Scheu et al. 1999; Eisenhauer and Scheu 2008). While the increase in nutrient availability in the presence of earthworms could increase plant resistance against herbivores, this effect has never been demonstrated in the field. Another way that earthworms could benefit agricultural crop production would be to control weeds, which is possible through their ability to modify seed germination by burial, ingestion, and maternal effects (Laossi et al. 2010b). This idea is supported by the influence of earthworms on natural plant community structure, which can increase or decrease plant density depending on the plant and earthworm species (Decaëns et al. 2003; Hale et al. 2008; Laossi et al. 2009; Eisenhauer et al. 2009), but needs to be confirmed in agroecosystems to determine whether a reduction in herbicide use is possible when earthworms are abundant.

Earthworm interactions with other soil organisms have received less investigation. For instance, the spreading of symbionts, i.e., mycorrhizae, carried by earthworms colonizing new fields was shown by Gange (1993), and Doube et al. (1994) demonstrated that earthworms can increase the nodulation of legume plants by Rhizobium. However, to our knowledge, crop production in response to an earthworm-enhanced redistribution of mycorrhizae or Rhizobium has never been assessed.
Greater production of plant growth regulators in the presence of earthworms was demonstrated (Canellas et al. 2002; Muscolo et al. 1998). These compounds could include signal molecules such as auxin or ethylene produced in earthworm casts, as demonstrated with loss-of-function mutants of Arabidopsis thaliana and transcriptome analysis of earthworm effects on plant development and defense (Puga-Freitas et al. 2012a). The stimulation of cultivable bacteria producing indoleacetic acid, an auxin compound, was also demonstrated (Puga-Freitas et al. 2012b).

Most of these findings regarding effects of earthworms on plant growth and health are positive but tend to be from studies under controlled conditions. Due to the great number of processes involved and the variability of field conditions, it is difficult to confirm these effects in agroecosystems, indicating that more research is needed on earthworm-plant interactions in real environments.

\section{Effects of cultural practices on earthworm communities in cropped fields}

Cultural practices are widely recognized to affect earthworms in agricultural fields (Lee 1985; Edwards and Bohlen 1996; Chan 2001; Roger-Estrade et al. 2010). Several studies have shown that earthworm abundance and diversity are reduced in agricultural fields, compared to uncropped soils (Edwards and Bohlen 1996; Peigne et al. 2009). Moreover, earthworms are more abundant in permanent pastures than those in annually cropped agroecosystems (Low 1972). The cultural practices most often cited for their effects on earthworm populations are tillage, crop sequence, organic fertilizers, and pesticide use, discussed further in the following sections.

\subsection{Tillage}

It is well known that tillage affects earthworm community structure and population dynamics. Tillage intensity, which can be defined as a combination of (i) working depth, (ii) fragmentation mode, and (iii) frequency of operations, is a major controller of earthworm population size and diversity. The working depth could be superficial, to a depth of 5-10 cm in a shallowly harrowed soil, or extensive in soils that are subject to full-inversion plowing (to a depth of $15-20 \mathrm{~cm}$ ) and subsoiling (below $20-\mathrm{cm}$ depth) operations. Fragmentation of surface litter is greater in soils that are rototilled than with some conservation tillage equipment (e.g., chisel plow with sweeps) or shallow harrows (e.g., chain harrow used for burying seed). The frequency of operations could be high, especially in organic farming (OF) systems where tillage is widely used to control weeds. Ivask et al. (2007) showed that earthworm populations are sensitive to tillage frequency. 
Earthworms are affected by tillage through several mechanisms (Chan 2001; Curry 2004; Roger-Estrade et al. 2010). The main, direct impact is the mechanical damage of earthworms that causes physical injuries or death following contact with tillage tools or soil clods moved during the tillage (Gerard and Hay 1979). Boström (1995) estimated that 61 to $68 \%$ of the earthworm biomass present in the soil layer tilled by a rotary hoe was killed by the tool. Soil inversion by plowing exposes earthworms to predators by moving deepdwelling earthworms to the soil surface (Cuendet 1983; Tomlin and Miller 1988) and also causes desiccation or frost damage to cocoons when tillage operations occur in autumn after crop harvest (House and Parmelee 1985). Conventional tillage (plowing and secondary tillage operations) destroys earthworm burrows, removes the insulating layer of litter, modifies organic matter availability due to burial of crop residues (Lee 1985; Nuutinen 1992; Briones and Bol 2003), and changes soil physical conditions such as temperature, moisture, and soil structure (Birkas et al. 2004; RosasMedina et al. 2010). Soil compaction, which can occur when wet soils are cultivated, has a detrimental effect on earthworm communities, inducing earthworm avoidance of compacted zones and earthworm death due to crushing by machinery (Capowiez et al. 2009; Cluzeau et al. 1992; Larink and Schrader 2000).

The less intensively the soil is disturbed, the less harmful tillage is for the earthworms. Thus, superficial tillage was less harmful for earthworms than ploughing. The impact of ploughing on earthworms was reviewed extensively (Edwards and Bohlen 1996; Chan 2001; Kladivko 2001). Even if ploughing is generally detrimental to earthworms, results vary across agroecosystems. After 5 years of cultivation with ploughing, there was a decrease of approximately $70 \%$ in earthworm biomass and $80 \%$ in earthworm numbers (Chan 2001). However, Evans and Guild (1948) found that a single spring ploughing did not significantly reduce the biomass or total number of earthworms. Rosas-Medina et al. (2010) found no difference between shallow tillage, disk ploughing, and ripper decompaction on earthworm abundance and biomass. Pelosi et al. (2009) found three to seven times more anecic and epigeic earthworms in a direct seeded system with living mulch treatment than those in conventional or organic farming systems with ploughing, and there were approximately two times more endogeic earthworms in conventional and organic farming ploughed systems than those in the direct seeded system.

As indicated by the findings of Pelosi et al. (2009), earthworm ecological groups respond differently to soil tillage (Ivask et al. 2007; Capowiez et al. 2009). Epigeic earthworms are negatively impacted by ploughing, as they cannot access to their trophic resource after burial of crop residues into the soil. The anecic group is probably the most negatively impacted by soil tillage because anecic species tend to be large, which makes them vulnerable to mechanical damage. Their vertical burrows are permanent and used as shelters - in contrast to the temporary burrows of endogeic species - as well as an access route to crop litter (their main food source) at the soil surface. Destruction of anecic burrows by tillage likely has a negatively impact on anecic earthworms. Peigne et al. (2009) explained that the increase in earthworm abundance in their no-till treatment was due to greater numbers of anecics. Endogeic earthworms seem to be less impacted, and even sometimes favored by ploughing, as their access to organic matter is facilitated when crop residues are buried and partially decomposed by soil microorganisms (Nuutinen 1992; Wyss and Glasstetter 1992). The endogeic earthworm A. caliginosa was considered to be tolerant of soil tillage (Peigne et al. 2009; Rosas-Medina et al. 2010) although de Oliveira et al. (2012) found it to be more sensitive to tillage than $A$. rosea. Pelosi et al. (2009) estimated that endogeic earthworms represented $75 \%$ of total earthworm populations in ploughed fields (conventional and organic farming systems) and only $36 \%$ in unploughed ones (direct seeded system). We suggest that contrasting response of earthworm populations to tillage in these field studies is due to the variability in the abundance and structure of earthworm populations during the year and between years. Thus, in field studies, the choice of the sampling date is crucial. A given tillage operation probably has a different effect on a population with a high proportion of juveniles than that on a population dominated by aged adults because juveniles may be more susceptible to mechanical damage and lack of food availability than adults. Moreover, the sensitivity of the different stages likely depends on the earthworm species. Thus, better description of the impact of tillage on earthworm communities requires monitoring throughout the year and for several years in adjacent agroecosystems with no-till and tillage treatments. These data could calibrate population dynamics models, to have an idea of the earthworm dynamics in undisturbed soils and finally analyze the effect of tillage practices on earthworm population dynamics.

Therefore, farmers who want to protect (or enhance) earthworm diversity and abundance in their fields have to carefully choose the tillage system they use (a light harrow for instance is better than a more aggressive rototiller for secondary tillage), the scheduling (prefer tillage in winter than in spring, because at that period, the population is dominated by juvenile that are more sensitive to tillage than adults), and the intensity (prefer unploughed than ploughed systems whenever possible). Direct drilling with direct seeding/no-till equipment is the most earthworm-friendly tillage practice. However, this type of crop management often poses challenges for weed control. Innovative approaches for the application of conservation tillage, such as perennial mulches, mechanical control of cover crops, rotational tillage, and others still need to be assessed for their impact on earthworms (Peigné et al. 2007). 


\subsection{Organic amendments}

Applying organic matter to agroecosystems is favorable to earthworm communities (increasing abundance and/or species diversity), regardless of the product applied (crop residue, green waste, cattle manure, etc.), since dead organic matter is the food of earthworms. However, the extent to which earthworm populations and species diversity increases depends on the amount and quality of organic amendments applied to the soil and the feeding habits of earthworm species (described above, for the epigeic, endogeic, and anecic ecological groups).

The quality of crop residues and organic amendments applied to the soil influences the humus content and consequently benefits endogeic earthworms that feed on humidified organic matter. Since the humification process is, among other things, controlled by the carbon to nitrogen ratio of the residues, the biochemical composition of residues could be considered as a qualitative indicator of the food resources supplied to endogeic earthworms. Thus, the crop sequence (including cover crops) is important to consider, because it determines the biochemical composition of the organic matter entering the agroecosystem.

Many agricultural systems have integrated cropping and livestock production, which is a source of animal manure (often from cattle) that serves as food for earthworms. Dung from various herbivores as an organic substrate for earthworm populations was reported by Scown and Baker (2006). These authors found that horse dung was generally preferred by five earthworm species (A. trapezoides, Microscolex dubius, M. phosphoreus, Spenceriella macleayi, and S. bywongensis). Leroy et al. (2008) compared farmyard manure, cattle slurry, and various composts on field earthworm populations. Two and a half years after the first organic matter application, the farmyard manure and cattle slurry treatments had the largest number of earthworms (about 800-900 individuals $\mathrm{m}^{-2}$ ), while the unamended controls had the lowest earthworm abundance (about 150 individuals $\mathrm{m}^{-2}$ ). The three compost treatments had intermediate values (400-500 individuals $\mathrm{m}^{-2}$ ).

Due to the paucity of data describing the response of field earthworm populations to quantity or quality of organic amendments originating from crop residues and other sources, it is not clear how to designing farming systems with appropriate organic matter inputs to maximize earthworm abundance and diversity.

\subsection{Pesticide application}

Most data about pesticide effect on earthworms come from standard laboratory tests with the epigeic Eisenia fetida, a compost-dwelling earthworm that is absent from agricultural fields. Due to the distinct life cycle and ecological niche of
E. fetida, it is challenging to determine how normal fielddwelling earthworms will respond to pesticides (Pelosi et al. 2014). The pathways and duration of exposure to potentially toxic compounds in pesticides (active compounds and adjuvants) need to be considered for field-dwelling earthworms.

Fungicides and insecticides are reported to be directly toxic to earthworms (Pelosi et al. 2014). However, they are frequently sprayed on foliage of crops after canopy closure, so that earthworms are not directly in contact with these pesticides and do not ingest them; unless, it rains shortly after spraying (washing pesticides off the foliage, bringing them into the soil), or if contaminated leaves fall onto the soil. Copper-based fungicides, common in organic farming, can be toxic to earthworms. In South Africa, Eijsackers et al. (2005) studied the direct toxic action of copper oxychloride on earthworms in vineyards and showed that copper could accumulate in earthworm. This element reduced growth and survival and induced behaviors such as a low burrowing rate and avoidance of copper-contaminated soils. Molluscicides may endanger anecic earthworm populations if the application is followed by a rainy period that causes anecic earthworms to move to the surface, where they may ingest the product. Vermifuges used for cattle care are excreted in dung, where the vermifuge products or their derivatives can be ingested by earthworms, although Svendsen et al. (2005) reported limited impact of vermifuges on the life cycle of earthworms. Herbicides from various chemical families have a wide range of toxicity for earthworms. For instance, Mohasin et al. (2005) have showed that paraquat applied at commercial dose induced a stronger decrease in cast formation, compared to a control plot without herbicide application, than glyphosate also applied at commercial dose. Herbicide applications are made on the soil surface, prior to planting or following weed and crop emergence, so that epigeic and anecic earthworms that feed on surface litter may be impacted by herbicides.

Exposure pathways differ for each type of pesticide and can be coupled with information on earthworm habitat and feeding preferences to draw some general conclusions about how pesticides affect earthworms. Endogeic earthworms are not directly exposed to pesticides sprayed on crop foliage or on the soil surface, and they do not feed on fresh organic matter that may contain pesticide residues. Therefore, their exposure to pesticides is expected to be low. Epigeic earthworms are the most exposed to agrochemicals, as they live and feed at the soil surface. Anecic earthworms are also exposed to pesticides as they feed on plant litter found on the soil surface. Pesticide impacts on earthworm communities are expected to be greater in no-till than tilled agroecosystems for two reasons: (i) Endogeic species dominate earthworm communities in conventionally tilled fields, and their life history traits reduce their exposure to pesticides, and (ii) no-till fields have greater reliance on herbicides for weed control, and this is likely to increase exposure to pesticides of epigeic and anecic earthworms, which 
represent the larger proportion of the earthworm communities in no-till agroecosystems.

Toxicity of pesticides to earthworms is difficult to assess from laboratory experiments because effective pesticide application rates in the field are generally low compared to toxic levels used in laboratory experiments. Under field conditions, lethal effects are rarely observed when the products are used at normal application rates, but sublethal effects on growth and reproduction may occur, depending on the earthworm species and product used (Bauer and Römbke 1997). For example, Choo and Baker (1998) reported no significant reduction of growth after 5 weeks of exposure to endosulfan (insecticide) and fenamiphos (used as an insecticide and a nematicide) but a significant growth reduction with ridomil (fungicide) and methiocarb (used as bird repellent, insecticide, acaricide, and molluscicide).

Therefore, the conclusion that can be drawn from available literature is that most data on pesticide toxicity to earthworms is based on E. fetida response in standard tests with well-fed earthworms having optimal population density. A more realistic assessment of ecotoxicological risk to pesticides requires information that better reflects the potential exposure in the field, with typical pesticide application rates and considering earthworm population dynamics in response to fluctuating environmental conditions (Menezes-Oliveira et al. 2011).

\section{Managing earthworm beneficial effects in cropped fields}

Increasing biodiversity in cropping systems is the key to improve agriculture sustainability, and diverse earthworm communities can contribute positively to this objective (Brussaard et al. 2007; Malezieux 2012). Depending on farmers' objectives, there are a variety of strategies to promote earthworm populations and earthworm services for agricultural crops. As illustrated in Fig. 4, these strategies range from those requiring minimal human intervention (self-organized ecosystems) to those that require considerable human intervention, including the use of earthworm-engineered products.

The first way to maintain large earthworm populations is by adopting practices that conserve earthworms or allow them to recolonize fields. Earthworm communities within agroecosystems can be considered to function as metacommunities (Mouquet and Loreau 2003), meaning that their abundance and diversity vary with land use (e.g., permanent pastures generally host larger earthworm populations than wheat fields). Managing earthworms across the landscape context implies that land owners should retain enough patches of land with earthworm-friendly land uses to serve as sources of earthworms (i.e., spatially control earthworm populations). Temporally, farmers can select crop rotations that include phases with earthworm-friendly crops/land uses to increase depleted earthworm populations. To achieve these objectives, it is necessary to modify the cropping systems at the farm scale or landscape scale to introduce cultural practices that are beneficial for earthworms and avoid practices that are detrimental to earthworms. Still, these practices must sustain crop production and allow farmers to meet crop yield targets. For instance, reduction in tillage intensity is favorable to earthworms, but, if adopted, alternative weed control measures are needed, e.g., using cover crops and/or living mulches, to avoid yield losses. Other practices that are beneficial to both earthworms and crops could represent win-win strategies. For instance, increasing the organic matter inputs to the soil or liming to bring the $\mathrm{pH}$ to a level favorable to earthworms and crops. These actions not only promote earthworm populations but could be the beginning of a virtuous circle: Adding organic matter or buffering soil $\mathrm{pH}$ promotes earthworm density but also improves soil structure and SOM cycling through beneficial earthworm-microbial interactions. In turn, greater soil biological activity can positively stimulate crop growth, leading to greater organic matter inputs from crop residues. This point is particularly important because agricultural activities tend to decrease SOM worldwide (Lal 2004).

The second way to increase earthworm abundance is to inoculate them directly into the field. However, this relies on the existence of an earthworm production unit or a commercial source of earthworms. Earthworms can be introduced without organic matter, but there should be enough organic matter in the field to meet the feeding requirements of the introduced and indigenous (if any) earthworm populations. Adding organic matter with earthworms is possible, but organic matter has then to be retrieved from outside the field, which makes the technique dependent on the cultural system and/or the socioeconomical context.

From laboratory breeding, it seems that the development stage of the introduced earthworms must be considered, as cocoons and juveniles are more adaptable to the transfer from one soil to another than adults. Earthworm inoculation units (Butt et al. 1997) are plastic bags containing the three earthworm life stages (cocoons, juveniles, and adults) that are emptied in field holes. This technique increases the success of colonization, as it involves addition of a structured population. The Stockdill method (Stockdill 1959, 1966, 1982; Martin and Stockdill 1976) is based on transplanting soil blocks with earthworms from adjacent ecosystems to the agroecosystem. This method aims to introduce earthworms from all life stages within an intact matrix of soil and associated organisms. However, this technique can be damaging for the ecosystem where soil blocks are retrieved.

At the other end of the gradient (Fig. 2), services provided by earthworm populations can be accessed by using products engineered by earthworms in semi-industrial production systems. Spreading of earthworm-created products, such as vermicompost, enters this category. Vermicompost, a mesophilic 


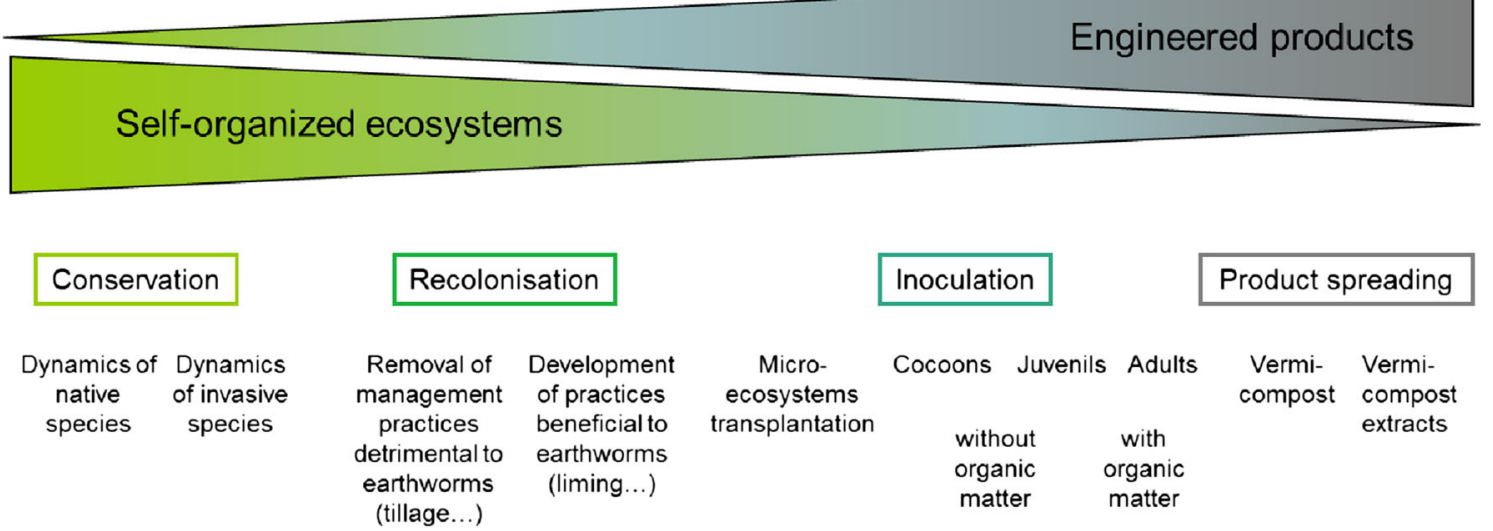

Fig. 4 There are several approaches to increase earthworm beneficial effects on crops and agroecosystems. The gradient depicted in this illustration distinguishes systems that function on the basis of self-

organization from systems that rely on human intervention to achieve their ecological functions. Modified from Blouin et al. 2013

compost made by earthworms, is produced from organic wastes; so, this solution could be very efficient for farmers with livestock operations as well as field crop cultivation. In fact, animal wastes could be vermicomposted at the farm, generally using the earthworm species $E$. fetida, and then spread with a minimal transport cost. The use of vermicompost extracts is also possible, but the cost associated with extraction prohibits their use in fieldscale agriculture. However, they can be used in plant nurseries to fortify young seedlings (Edwards et al. 2011).

Despite all these techniques, there are few long-term field experiments examining earthworm impacts on soil fertility and crop yield, partially because it is difficult to control earthworm abundance in large plots so that high and low earthworm abundances could be compared among agricultural treatments (e.g., to evaluate the effects of tillage, organic matter amendments, mineral fertilizer, pesticides). Therefore, despite many indirect arguments and results demonstrating the beneficial effect of earthworms on crop growth and yield the short term, it is difficult to scientifically assess the long-term benefits of increasing earthworm abundance in cropped fields.

In the same vein, all components of agroecosystems interact, and the choice of the plant is probably important for determining earthworm-crop interactions. For example, some crops are probably more beneficial for earthworms because they produce more crop residues (e.g., higher root biomass) or lead to the accumulation of SOM stocks that can serve as food for earthworms. For the same reason, different cultivars of the same crop plant are likely to impact earthworms differently, but how cultivar traits impact earthworms has hardly been studied. Reciprocally, earthworms are likely to affect differently diverse plant cultivars. For instance, rice cultivars respond differently to the presence of earthworms (Noguera et al. 2011). This suggests that choosing the right cultivar or developing new cultivars that interact well with earthworms could amplify the benefit of earthworm-friendly cropping systems. Modern cultivars were developed principally for

their high yields and quick growth, and no effort was made to select cultivars that interact fruitfully with soil biodiversity (Loeuille et al. 2013). This represents an important research avenue to promote soil biodiversity for better crop production in the context of sustainable agriculture.

Due to the inadequate number of long-term field experiments on earthworms, the site-specific nature of earthworm services to crops and the absence of socioeconomic evaluation of techniques to increase earthworm numbers, the promotion of earthworm in agricultural fields is still anecdotal. However, increasing knowledge about their contribution to soil functioning and about the ecosystem services they provide is stimulating enthusiasm for earthworm experiments by farmers and researchers. This growing interest will probably fill knowledge gaps and provide socioeconomic information regarding the opportunity to promote earthworms in cropping systems. In any case, earthworms are key actors in soil biodiversity, and they will likely be important in the development of innovative, sustainable cropping systems in the foreseeable future.

\section{Conclusion}

Overall, earthworm effects on soil fertility and plant growth are positive. They improve soil structure and stabilize SOM fractions within their casts. In the short term, they increase mineralization, which make mineral nutrients available for plants. Earthworm trigger the release of molecules analoguous to phytohormones that tend to improve plant growth. Tillage is generally detrimental to earthworms whereas practices increasing SOM content positively impact earthworm communities. The impact of pesticide of earthworms is incompletely understood because of the lack of field data on the actual exposure of earthworms to currently used molecules. Alltogether, using earthworm services in cropping systems is

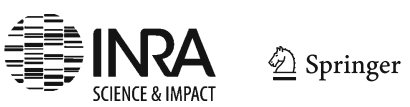


very likely to contribute increasing agricultural sustainability. Nevertheless, additional long-term field studies will be essential to fully understand the impact of earthworms on crop production. In particular, these studies should strive to (i) disentangle the mechanisms through which earthworms impact fertility and plant growth and (ii) assess the relative influence of agricultural practices on earthworm populations

\section{References}

Appelhof M, Fenton MF, Harris BL (1993) Worms eat our garbage. Classroom activities for a better environment. Flower Press, Kalamazoo, p 214

Arancon NQ, Edwards CA (2011) The use of vermicomposts as soil amendments for production of field crops. In: Edwards CA, Arancon NQ, Sherman R (eds) Vermiculture technology: earthworms, organic wastes, and environmental management. CRC Press, Boca Raton, pp 129-151

Atiyeh RM, Dominguez J, Subler S, Edwards CA (2000) Changes in biochemical properties of cow manure during processing by earthworms (Eisenia andrei, Bouche) and the effects on seedling growth. Pedobiologia 44:709-724. doi:10.1078/S0031-4056(04)70084-0

Baker GH, Carter PJ, Barrett VJ (1999) Influence of earthworms, Aporrectodea spp. (Lumbricidae), on pasture production in southeastern Australia. Aust J Agric Res 50:1247-1257. doi:10.1071/ AR98182

Bauer C, Römbke J (1997) Factors influencing the toxicity of two pesticides on three lumbricid species in laboratory tests. Soil Biol Biochem 29:705-708. doi:10.1016/S0038-0717(96)00198-8

Birkas M, Jolankai M, Gyuricza C, Percze A (2004) Tillage effects on compaction, earthworms and other soil quality indicators in Hungary. Soil Tillage Res 78:185-196. doi:10.1016/j.still.2004. 02.006

Blackwell PS (2000) Management of water repellency in Australia, and risks associated with preferential flow, pesticide concentration and leaching. J Hydrol 231(232):384-395. doi:10.1016/ S0022-1694(00)00210-9

Blanchart E, Lavelle P, Braudeau E, Le Bissonnais Y, Valentin C (1997) Regulation of soil structure by geophagous earthworm activities in humid savannas of Côte d'Ivoire. Soil Biol Biochem 29:431-439. doi:10.1016/S0038-0717(96)00042-9

Blanchart E, Albrecht A, Alegre J, Duboisset A, Gilot C, Pashanasi B, Lavelle P, Brussaard L (1999) Effects of earthworms on soil structure and physical properties. In: Lavelle P, Brussaard L, Hendrix P (eds) Earthworm management in tropical agroecosystems. CAB International, Wallingford, pp 149-172

Blouin M, Zuily-Fodil Y, Pham-Thi AT, Laffray D, Reversat G, Pando A, Tondoh J, Lavelle P (2005) Belowground organism activities affect plant aboveground phenotype, inducing plant tolerance to parasites. Ecol Lett 8:202-208. doi:10.1111/j.1461-0248.2004.00711.x

Blouin M, Lavelle P, Laffray D (2007) Drought stress in rice (Oryza sativa L.) is enhanced in the presence of the compacting earthworm Millsonia anomala. Environ Exp Bot 60:352-359. doi:10.1016/j. envexpbot.2006.12.017

Blouin M, Hodson ME, Delgado EA, Baker G, Brussaard L, Butt KR, Dai J, Dendooven L, Peres G, Tondoh JE, Cluzeau D, Brun JJ (2013) A review of earthworm impact on soil function and ecosystem services. Eur J Soil Sci 64:161-182. doi:10.1111/ejss.12025

Bohlen PJ, Parmelee RW, McCartney DA, Ewards CA (1997) Earthworm effects on carbon and nitrogen dynamics of surface litter in corn agroecosystems. Ecol Appl 7:1341-1349. doi:10.1890/ 1051-0761(1997)007[1341:EEOCAN]2.0.CO;2

Bossuyt H, Six J, Hendrix PF (2005) Protection of soil carbon by microaggregates within earthworm casts. Soil Biol Biochem 37: 251-258. doi:10.1016/j.soilbio.2004.07.035

Boström U (1995) Earthworm populations (Lumbricidae) in ploughed and undisturbed leys. Soil Tillage Res 35:125-133. doi:10.1016/ 0167-1987(95)00489-0

Bouché M.B., (1972) Lombriciens de France. Ecologie et systematique, INRA, Ann. Zool. Anim. Publication, Paris, 671 pp

Bouché M, Al-Addan F (1997) Role of earthworms in the N cycle: a falsifiable assessment. Soil Biol Biochem 29:375-380. doi:10.1016/ S0038-0717(96)00045-4

Briones MJI, Bol R (2003) Natural abundance of C-13 and N-15 in earthworms from different cropping treatments. Pedobiologia 47: 560-567. doi:10.1016/S0031-4056(04)70238-3

Brown GG (1995) How do earthworms affect microfloral and faunal community diversity? Plant Soil 170:209-231. doi:10.1007/ BF02183068

Brown GG, Pashanasi B, Villenave C, Patron JC, Senapati BK, Giri S, Barois I, Lavelle P, Blanchart E, Blakemore RJ, Spain AV, Boyer J (1999) Effects of earthworms on plant production in the tropics. In: Lavelle P, Brussaard L, Hendrix P (eds) The management of earthworms in tropical agroecosystems. CAB International, Wallingford, pp 87-148

Brown GG, Edwards CA, Brussaard L (2004) How earthworms affect plant growth: burrowing into the mechanisms. In: Edwards CA (ed) Earthworm ecology. CRC Press, Boca Raton, pp 13-49

Brussaard L, de Ruiter PC, Brown GG (2007) Soil biodiversity for agricultural sustainability. Agric Ecosyst Environ 121:233-244. doi:10.1016/j.agee.2006.12.013

Burtelow AE, Bohlen PJ, Groffman PM (1998) Influence of exotic earthworm invasion on soil organic matter, microbial biomass and denitrification potential in forest soils of the northeast United States. Appl Soil Ecol 9:197-202. doi:10.1016/S09291393(98)00075-4

Butt KR, Frederickson J, Morris RM (1997) The earthworm inoculation unit technique: an integrated system for cultivation and soilinoculation of earthworms. Soil Biol Biochem 29:251-257. doi: 10.1016/S0038-0717(96)00053-3

Canellas LP, Olivares FL, Okorokova-Facanha AL, Facanha AR (2002) Humic acids isolated from earthworm compost enhance root elongation, lateral root emergence, and plasma membrane $\mathrm{H}+-$ ATPase activity in maize roots. Plant Physiol 130:1951-1957. doi:10.1104/ pp. 007088

Capowiez Y, Cadoux S, Bouchant P, Ruy S, Roger-Estrade J, Richard G, Boizard H (2009) The effect of tillage type and cropping system on earthworm communities, macroporosity and water infiltration. Soil Tillage Res 105:209-216. doi:10.1016/j.still.2009.09.002

Carpenter D, HodsonM E, Eggleton P, Kirk C (2007) Earthworm induced mineral weathering: preliminary results. Eur J Soil Biol 43:S176 S183. doi:10.1016/j.ejsobi.2007.08.053

Chan KY (2001) An overview of some tillage impacts on earthworm population abundance and diversity - implications for functioning in soils. Soil Tillage Res 57:179-191. doi:10.1016/S0167-1987(00) 00173-2

Chan KY, Baker GH, Conyers MK, Scott B, Munro K (2004) Complementary ability of three European earthworms (Lumbricidae) to bury lime and increase pasture production in acidic soils of southeastern Australia. Appl Soil Ecol 26:257-271. doi:10.1016/j.apsoil. 2003.12.004

Chauvel A, Grimaldi M, Barros E, Blanchart E, Desjardins T, Sarrazin M, Lavelle P (1999) Pasture damage by an Amazonian earthworm. Nature 398:32-33. doi:10.1038/17946

Choo L, Baker H (1998) Influence of four commonly used pesticides on the survival, growth, and reproduction of the earthworm Apporectodea 
trapezoides (Lumbricidae). Aust J Agric Res 49:1297-1303. doi:10. 1071/A98021

Clements RO, Murray PJ, Sturdy RG (1991) The impact of 20 years absence of earthworms and 3 levels of $\mathrm{N}$-fertilizer on a grassland soil. Agric Ecosyst Environ 36:75-85. doi:10.1016/0167-8809(91) 90037-X

Cluzeau D, Binet F, Vertes F, Simon JC, Riviere JM, Trehen P (1992) Effects of intensive cattle trampling on soil plant earthworms system in 2 grassland types. Soil Biol Biochem 24:1661-1665. doi:10. 1016/0038-0717(92)90166-U

Costello DM, Lamberti GA (2009) Biological and physical effects of non-native earthworms on nitrogen cycling in riparian soils. Soil Biol Biochem 41:2230-2235. doi:10.1016/j.soilbio.2009.08.007

Cuendet G (1983) Predation on earthworms by the black-headed gull (Larusridibundus L.). In: Satchell JE (ed) Earthworm ecology - from Darwin to Vermiculture. Chapman \& Hall, London, pp 415-424

Curry JP (2004) Factors affecting the abundance of earthworms in soils. In: Edwards CA (ed) Earthworm ecology. CRC, Boca Raton, pp $115-188$

Darwin C (1881) The formation of vegetable mould through the action of worms, with observations on their habits. John Murray, London

De Oliveira T, Bertrand M, Roger-Estrade J (2012) Short-term effects of ploughing on the abundance and dynamics of two endogeic earthworm species in organic cropping systems in northern France. Soil Tillage Res 119:76-84. doi:10.1016/j.still.2011.12.008

Decaëns T, Mariani L, Betancourt N, Jiménez JJ (2003) Seed dispersion by surface casting activities of earthworms in Colombian grasslands. Acta Oecol 24:175-185. doi:10.1016/S1146-609X(03)00083-3

Domínguez J, Bohlen PJ, Parmelee RW (2004) Earthworms increase nitrogen leaching to greater soil depths in row crop agroecosystems. Ecosytems 7:672-685. doi:10.1007/s10021-004-0150-7

Don A, Steinberg B, Schöning I, Pritsch K, Joschko M, Gleixner G, Schulze E-D (2008) Organic carbon sequestration in earthworm burrows. Soil Biol Biochem 40:1803-1812. doi:10.1016/j.soilbio. 2008.03.003

Doube BM, Ryder MH, Davoren CW, Stephens PM (1994) Enhanced root nodulation of subterranean clover (Trifolium subterraneum) by Rhizobium leguminosarium biovartrifolii in the presence of the earthworm Aporrectodea trapezoides (Lumbricidae). Biol Fertil Soils 18:169-174. doi:10.1007/BF00647663

Edwards CA (2004) Earthworm ecology. CRC Press, Boca Raton

Edwards CA, Bohlen PJ, (1996) Ed., Biology and ecology of earthworms. Chapman \& Hall, London, $426 \mathrm{p}$

Edwards CA, Arancon NQ, Sherman R (2011) Vermiculture technology: earthworms, organic wastes, and environmental management. CRC Press, Boca Raton, p 601

Ehlers W (1975) Observations on earthworm channels and infiltration on tilled and untilled loess soil. Soil Sci 119:242-249. doi:10.1097/ 00010694-197503000-00010

Eijsackers H, Beneke P, Maboeta M, Louw JPE, Reinecke AJ (2005) The implications of copper fungicide usage in vineyards for earthworm activity and resulting sustainable soil quality. Ecotoxicol Environ Saf 62:99-111. doi:10.1016/j.ecoenv.2005.02.017

Eisenhauer N, Scheu S (2008) Earthworms as drivers of the competition between grasses and legumes. Soil Biol Biochem 40:2650-2659. doi:10.1016/j.soilbio.2008.07.010

Eisenhauer N, Schuy M, Butenschoen O, Scheu S (2009) Direct and indirect effects of endogeic earthworms on plant seeds. Pedobiologia 52:151-162. doi:10.1016/j.pedobi.2008.07.002

Eriksen-Hamel NS, Whalen JK (2007) Impacts of earthworms on soil nutrients and plant growth in soybean and maize agroecosystems. Agric Ecosyst Environ 120:442-448. doi:10.1016/j.agee.2006. 11.004

Ernst G, Felten D, Volhand M, Emmerling C (2008) Impact of ecologically different earthworm species on soil water characteristics. Eur J Soil Biol 45:207-213. doi:10.1016/j.ejsobi.2009.01.001
Evans AC, Guild WJM (1948) Studies on the relationships between earthworms and soil fertility; chapter V. Field population. Appl Biol 35:485-493

Fontaine S, Barot S, Barré P, Bdioui N, Mary B, Rumpel C (2007) Stability of organic carbon in deep soil layers controlled by fresh carbon supply. Nature 450:277-281. doi:10.1038/nature06275

Gange AC (1993) Translocation of mycorrhizal fungi by earthworms during early succession. Soil Biol Biochem 25:1021-1026. doi:10. 1016/0038-0717(93)90149-6

Gerard BM, Hay RKM (1979) The effect on earthworms of ploughing, tined cultivation, direct drilling and nitrogen in a barley monoculture system. J Agric Sci 93:147-155. doi:10. 1017/S0021859600086238

Giri S (1995) Short term input operational experiment in tea garden with application of organic matter and earthworms. M. Phil. Thesis, Sambalpur University Sambalpur, India

Grdiša M, Gršić K, Grdiša MD (2013) Earthworms - role in soil fertility to the use in medicine and as a food. Invertebr Surviv J 10:38-45

Groffman PM, Bohlen PJ, Fisk MC, Fahey TJ (2004) Exotic earthworm invasion and microbial biomass in temperate forest soils. Ecosystems 7:45-54. doi:10.1007/s10021-003-0129-9

Hale CM, Frelich LE, Reich PB, Pastor J (2008) Exotic earthworm effects on hardwood forest floor, nutrient availability and native plants: a mesocosm study. Oecologia 155:509-518. doi:10.1007/s00442007-0925-6

Hallaire V, Curmi P, Duboisset A, Lavelle P, Pashanasi B (2000) Soil structure changes induced by the tropical earthworm Pontoscolex corethrurus and organic inputs in a Peruvian ultisol. Eur J Soil Biol 36:35-44. doi:10.1016/S1164-5563(00)01048-7

Hendrix PF, Peterson AC, Beare MH, Coleman DC (1998) Long-term effects of earthworms on microbial biomass nitrogen in coarse and fine textured soils. Appl Soil Ecol 9:375-380. doi:10.1016/S09291393(98)00092-4

Horn MA, Mertel R, Gehre M, Kästner M, Drake HL (2006) In vivo emission of dinitrogen by earthworms via denitrifying bacteria in the gut. Appl Environ Microbiol 72:1013-1018. doi:10.1128/AEM. 72. 2.1013-1018.2006

House GJ, Parmelee RW (1985) Comparison of soil arthropods and earthworms from conventional and no-tillage agroecosystems. Soil Tillage Res 5:351-360. doi:10.1016/S0167-1987(85)80003-9

Ivask M, Kuu A, Sizov E (2007) Abundance of earthworm species in Estonian arable soils. Eur J Soil Biol 43:S39-S42. doi:10.1016/j. ejsobi.2007.08.006

Jarvis N, Etana A, Stagnitti F (2007) Water repellency, near-saturated infiltration and preferential solute transport in a macroporous clay soil. Geoderma 143:223-230. doi:10.1016/j.geoderma.2007.11.015

Jegou D, Brunotte J, Rogasik H, Capowiez Y, Diestel H, Schrader S, Cluzeau D (2002) Impact of soil compaction on earthworm burrow systems using X-ray computed tomography: preliminary study. Eur J Soil Biol 38:329-336. doi:10.1016/S1164-5563(02)01148-2

Jouquet P, Podwojewski P, Bottinelli N, Mathieu J, Ricoy M, Orange D, Duc TT, Valentin C (2007) Above-ground earthworm casts affect water runoff and soil erosion in Northern Vietnam. Catena 74:1321. doi:10.1016/j.catena.2007.12.006

Kladivko EJ (2001) Tillage systems and soil ecology. Soil Tillage Res 61: 61-76. doi:10.1016/S0167-1987(01)00179-9

Lachnicht SL, Parmelee RW, Mccartney D, Allen M (1997) Characteristics of macroporosity in a reduced tillage agroecosystem with manipulated earthworm populations: Implications for infiltration and nutrient transport. Soil Biol Biochem 29:493-498. doi:10. 1016/S0038-0717(96)00106-X

Lal R (2004) Soil carbon sequestration impacts on global climate change and food security. Science 304:1623-1627. doi:10.1126/science. 1097396

Laossi K-R, Noguera DC, Bartolomé-Lasa A, Mathieu J, Blouin M, Barot S (2009) Effects of endogeic and anecic earthworms on the 
competition between four annual plants and their relative reproduction potential. Soil Biol Biochem 41:1668-1673. doi:10.1016/j. soilbio.2009.05.009

Laossi K.-R, Decaëns T, Jouquet P, Barot S (2010a). Can we predict how earthworm effects on plant growth vary with soil properties? Applied and Environmental Soil Science, Article ID 784342: 6. DOI: $10.1155 / 2010 / 784342$

Laossi K-R, Noguera D-C, Barot S (2010b) Earthworm-mediated maternal effects on seed germination and seedling growth in three annual plants. Soil Biol Biochem 42:319-323. doi:10.1016/j.soilbio.2009. 11.010

Larink O, Schrader S (2000) Rehabilitation of degraded compacted soil by earthworms, in Subsoil Compaction. Adv GeoEcol 32:284-294

Lavelle P, Martin A (1992) Small-scale and large-scale effects of endogeic earthworms on soil organic matter dynamics in soils of the humid tropics. Soil Biol Biochem 24:1491-1498. doi:10.1016/ 0038-0717(92)90138-N

Lavelle P, Spain AV (2001) Soil ecology. Kluwer Scientific Publications, Amsterdam

Lavelle P, Melendez G, Pashanasi B, Schaefer R (1992) Nitrogen mineralization and reorganization in casts of the geophagous tropical earthworm Pontoscolex corethrurus (Glossoscolecidae). Biol Fertil Soils 14:49-53. doi:10.1007/BF00336302

Lavelle P, Barois I, Blanchart E, Brown G, Decaëns T, Fragoso C, Jimenez JJ, Kajondo KK, Moreno A, Pashanasi B, Senapati B, Villenave C (2001) Earthworms as a resource in tropical agroecosystems. In: SubbaRao NS, Dommergues YR (eds) Microbial interactions in agriculture and forestry. Science Publishers, Inc., Enfield, pp 163-181

Le Bayon RC, Moreau S, Gascuel-Odoux C, Binet F (2002) Annual variations in earthworm surface-casting activity and soil transport by water runoff under a temperate maize agroecosytem. Geoderma 106: 121-135. doi:10.1016/S0016-7061(01)00121-5

Lee KE (1985) Ed.. Earthworms - Their ecology and relationships with soils and land use. Academic press, Australia, $411 \mathrm{p}$

Leroy BLM, Schmidt O, Van den Bossche A, Reheul D, Moens M (2008) Earthworm population dynamics as influenced by the quality of exogenous organic matter. Pedobiologia 52:139-150. doi:10.1016/ j.pedobi.2008.07.001

Li X, Fisk MC, Fahey TJ, Bohlen PJ (2002) Influence of earthworm invasion on soil microbial biomass and activity in a northern hardwood forest. Soil Biol Biochem 34:1929-1937. doi:10.1016/S00380717(02)00210-9

Loeuille N, Barot S, Georgelin E, Kylafis G, Lavigne C (2013) Ecoevolutionary dynamics of agricultural networks: implications for a sustainable management. Adv Ecol Res 49:339-435. doi:10.1016/ B978-0-12-420002-9.00006-8

Low AJ (1972) The effect of cultivation on the structure and other physical characteristics of grassland and arable soils (1945-1970). J Soil Sci 23:363-380. doi:10.1111/j.1365-2389.1972.tb01668.x

Lubbers IM, Groenigen KV, Fonte SJ, Six J, Brussaard L, Groenigen JW (2013) Greenhouse-gas emissions from soils increased by earthworms. Nature Climate Change. doi:10.1038/nclimate1692

Malezieux E (2012) Designing cropping systems from nature. Agron Sustain Dev 32:15-29. doi:10.1007/s13593-011-0027-z

Marinissen JCY, de Ruiter PC (1993) Contribution of earthworms to carbon and nitrogen cycling in agro-systems. Agric Ecosyst Environ 47:59-74. doi:10.1016/0167-8809(93)90136-D

Martin GA, Stockdill SMJ (1976) Machine speeds job of earthworm introduction. N Z J Agric 132:6-7

McLean MA, Parkinson D (2000) Field evidence of the effects of the epigeic earthworm Dendrobaena octaedra on the microfungal community in pine forest floor. Soil Biol Biochem 32:351-360. doi:10. 1016/S0038-0717(99)00161-3

Menezes-Oliveira VB, Scott-Fordsmand JJ, Rocco A, Soares AM, Amorim MJ (2011) Interaction between density and $\mathrm{Cu}$ toxicity for Enchytraeus crypticus and Eisenia fetida reflecting field scenarios. Sci Total Environ 409:3370-3374. doi:10.1016/j. scitotenv.2011.04.033

Mohasin M, Bhowmik P, Banerjee A, Somchoudhury A (2005) Effect of some herbicides on earthworm (Metaphireposthuma) under field conditions. J Crop Weed 1:17-19

Mouquet N, Loreau M (2003) Community patterns in source-sink metacommunities. Am Nat 162:544-557. doi:10.1086/378857

Muscolo A, Cutrupi S, Nardi S (1998) IAA detection in humic substances. Soil Biol Biochem 30:1199-1201. doi:10.1016/S00380717(98)00005-4

Noguera D, Laossi K-R, Lavelle P, Cruz de Carvalho M-H, Asakawa N, Botero C, Barot S (2011) Amplifying the benefits of agroecology by using the right cultivars. Ecol Appl 21:2349-2356. doi:10.1890/102204.1

Nuutinen V (1992) Earthworm community response to tillage and residue management on different soil types in southern Finland. Soil Tillage Res 23:221-239. doi:10.1016/0167-1987(92)90102-H

Olele NF, Okonkwo JC (2012) Replacement of fish meal with graded levels of earthworm meal in the diet of fingerlings: effect on feed and growth parameters. J Agric Sci Technol A 2:901-908

Paoletti M, Buscardo E, VanderJagt D, Pastuszyn A, Pizzoferrato L, Huang Y, Chuang L, Millson M, Cerda H, Torres F, Glew R (2003) Nutrient content of earthworms consumed by Ye'Kuana Amerindians of the Alto Orinoco of Venezuela. Proc R Soc B Biol Sci 270:249-257. doi:10.1098/rspb.2002.2141

Peigné J, Ball BC, Roger-Estrade J, David C (2007) Is conservation tillage suitable for organic farming? A review. Soil Use Manag 23: 129-144. doi:10.1111/j.1475-2743.2006.00082.x

Peigne J, Cannavaciuolo M, Gautronneau Y, Aveline A, Giteau JL, Cluzeau D (2009) Earthworm populations under different tillage systems in organic farming. Soil Tillage Res 104:207-214. doi:10. 1016/j.still.2009.02.011

Pelosi C, Bertrand M, Roger-Estrade J (2009) Earthworm community in conventional, organic and direct seeding with living mulch cropping systems. Agron Sustain Dev 29:287-295. doi:10.1051/agro/ 2008069

Pelosi C, Barot S, Capowiez Y, Hedde M, Vandenbulcke F (2014) Pesticides and earthworms. A review. Agron Sustain Dev 34:199 228. doi:10.1007/s13593-013-0151-z

Pitkänen J, Nuutinen V (1998) Earthworm contribution to infiltration and surface runoff after 15 years of different soil management. Appl Soil Ecol 9:411-415. doi:10.1016/S0929-1393(98)00098-5

Puga-Freitas R, Barot S, Taconnat L, Renou J-P, Blouin M (2012a) Signal molecules mediate the impact of the earthworm Aporrectodea caliginosa on growth, development and defence of the plant Arabidopsis thaliana. PLoS ONE 7:e49504. doi:10.1371/journal. pone.0049504

Puga-Freitas R, Abbad S, Gigon A, Garnier-Zarli E, Blouin M (2012b) Control of cultivable IAA-producing bacteria by the plant Arabidopsis thaliana and the earthworm Aporrectodea caliginosa. Appl Environ Soil Sci 2012, 307415. doi:10.1155/ 2012/307415

Pulleman MM, Six J, Uyl A, Marinissen JCY, Jongmans AG (2005) Earthworms and management affect organic matter incorporation and microaggregate formation in agriculture soils. Appl Soil Ecol 29:1-15. doi:10.1016/j.apsoil.2004.10.003

Reddell P, Spain AV (1991) Transmission of infective Frankia (Actinomycetales) propagules in casts of the endogeic earthworm Pontoscolex corethrurus (Oligocheta: Glossoscolecidae). Soil Biol Biochem 23:767-774. doi:10.1016/0038-0717(91)90148-D

Riley H, Pommeresche R, Eltun R, Hansen S, Korsaeth A (2008) Soil structure, organic matter and earthworm activity in a comparison of cropping systems with contrasting tillage, rotations, fertilizer levels and manure use. Agric Ecosyst Environ 124:275-284. doi:10.1016/ j.agee.2007.11.002 
Ritsema CJ, Dekker LW (2000) Preferential flow in water repellent sandy soils: principles and modeling implications. J Hydrol 231(232):308 319. doi:10.1016/S0022-1694(00)00203-1

Roger-Estrade J, Anger C, Bertrand M, Richard G (2010) Tillage and soil ecology: partners for sustainable agriculture. Soil Tillage Res 111: 33-40. doi:10.1016/j.still.2010.08.010

Rosas-Medina MA, de Leon-Gonzalez F, Flores-Macias A, Payan-Zelaya F, Borderas-Tordesillas F, Gutierrez-Rodriguez F, Fragoso-Gonzalez C (2010) Effect of tillage, sampling date and soil depth on earthworm population on maize monoculture with continuous stover restitutions. Soil Tillage Res 108:37-42. doi:10.1016/j.still.2010. 03.008

Sander T, Gerke HH, Rogasik H (2008) Assessment of Chinese paddysoil structure using X-ray computed tomography. Geoderma 145: 303-314. doi:10.1016/j.geoderma.2008.03.024

Scheu S (2003) Effects of earthworms on plant growth: patterns and perspectives. Pedobiologia 47:846-856. doi:10.1078/0031-405600270

Scheu S, Theenhaus A, Jones TH (1999) Links between the detritivore and the herbivore system: effects of earthworms and Collembola on plant growth and aphid development. Oecologia 119:541-551. doi: 10.1007/s004420050817

Scheu S, Schlitt N, Tunov AV, Newington JE, Jones TH (2002) Effects of the presence and community composition of earthwoms on microbial community functioning. Oecologia 133:254-260. doi:10.1007/ s00442-002-1023-4

Scown J, Baker G (2006) The influence of livestock dung on the abundance of exotic and native earthworms in a grassland in southeastern Australia. Eur J Soil Biol 42:310-315. doi:10.1016/j. ejsobi.2006.07.036

Shen Y (2010) Earthworms in traditional Chines medicine (Oligocaea: Lumbricidae, Megascolecidae). Zool Middle East, Suppl 2:171173. doi:10.1080/09397140.2010.10638470

Shuster WD, McDonald LP, McCartney DA, Parmelee RW, Studer NS, Stinner BR (2002) Nitrogen source and earthworm abundance affected runoff volume and nutrient loss in a tilled-corn agroecosystem. Biol Fertil Soils 35:320-327. doi:10.1007/s00374002-0474-4
Stephens PM, Davoren CW (1997) Influence of the earthworms Aporrectodea trapezoides and A. rosea on the disease severity of Rhizoctonia solani on subterranean clover and ryegrass. Soil Biol Biochem 29:511-516. doi:10.1016/S0038-0717(96)00108-3

Stephens PM, Davoren CW, Doube BM, Ryder MH (1994) Ability of the lumbricid earthworms Aporrectodea rosea and Aporrectodea trapezoides to reduce the severity of take-all under greenhouse and field conditions. Soil Biol Biochem 26:1291-1297. doi:10.1016/ 0038-0717(94)90209-7

Stockdill SMJ (1959) Earthworms improve pasture growth. N Z J Agric 98:227-233

Stockdill SMJ (1966) The effect of earthworms on pastures. Proc N Z Proc NZ Ecol Soc 13:68-75

Stockdill S (1982) Effects of introduced earthworms on the productivity of New Zealand pastures. Pedobiologia 24:29-35

Svendsen TS, Hansen PE, Sommer C, Martinussen T, Gronvold J, Holter P (2005) Life history characteristics of Lumbricus terrestris and effects of the veterinary antiparasitic compounds ivermectin and fenbendazole. Soil Biol Biochem 37:927-936. doi:10.1016/j. soilbio.2004.10.014

Tiroesele B, Moreki JC (2012) Termites and earthworms as potential alternative sources of protein for poultry. Int J Agro Vet Med Sci 6:368-376

Tomlin AD, Miller JJ (1988) Impact of ring-billed gull (Larus delawarensis ord.) foraging on earthworm populations of southwestern Ontario agricultural soils. Agric Ecosyst Environ 20:165173. doi:10.1016/0167-8809(88)90108-9

Valckx J, Pennings A, Leroy T, Berckmans D, Govers G, Hermy M, Muys B (2010) Automated observation and analysis of earthworm surface behaviour under experimental habitat quality and availability conditions. Pedobiologia 53:259-263. doi:10.1016/j.pedobi. 2009.12.005

Winding A, Rønn R, Hendriksen NB (1997) Bacteria and protozoa in soil microhabitats as affected by earthworms. Biol Fertil Soils 24:133140. doi:10.1007/s003740050221

Wyss E, Glasstetter M (1992) Tillage treatments and earthworm distribution in a swiss experimental corn field. Soil Biol Biochem 24:16351639. doi:10.1016/0038-0717(92)90162-Q 